\title{
Sumber Dana dan Persepsi Tentang Bunga Bank oleh Pedagang Muslim (Studi Pedagang di Pasar Basah di Kota Kendari Tahun 2015)
}

\author{
Nur Afandi ${ }^{1}$, Ernawati ${ }^{2}$ \\ Fakultas Ekonomi dan Bisnis Universitas Halu Oleo Indonesia \\ nurafandi011@yahoo.com¹; erna_unhalu@yahoo.com² \\ Masuk: 9 April 2018; Diterima: 6 Juni 2018; Terbit: 25 Juni 2018
}

\begin{abstract}
Fatwa of The Council of Indonesian Ulama (Majelis Ulama Indonesia, MUI) Number 1/2004 implies that bank interest is equal to usury. The purpose of this study was to determine Muslim traders' perceptions of interest, and their consistency in the behavior of loan applications. A method of data collection used in this study was questionnairesto Muslim traders of Wet Mandonga Market Kendari City. Samples taken in this research were 30 respondents with census sampling technique. The data were analyzed using percentage. The level of consistency of respondents is calculated by the share of the number of respondents who consider the bank interest equal to usury and do not make loans with conventional scheme, to the total respondents. The results showed that all Muslim traders in the Wet Market Mandonga Kendari City have understood that the interest is equal to usury, However there are 16.67 percent of respondents whose equity is usury, where 6.67 percent of which comes from loan shark. The consistency of perception and application of the understanding of interest money on Muslim traders reached 83.33 percent.
\end{abstract}

Keywords: perception; interest; usury; equity

\begin{abstract}
Abstrak
Fatwa Majelis Ulama Indonesia (MUI) Nomor 1 Tahun 2004 membawa pesan bahwa bunga bank sama dengan riba. Penelitian ini mengkaji persepsi pedagang muslim tentang bunga, dan konsistensinya terhadap perilaku pengajuan pinjaman modal. Metode pengumpulan data diperoleh melalui kuisioner bagi pedagang muslim di Pasar Basah Mandonga Kota Kendari. Sampel pada penelitian ini berjumlah 30 orang pedagang, yang ditentukan berdasarkan metode sensus. Metode analisis yang digunakan yaitu matriks empat kuadran dan persentase. Tingkat konsistensi responden dihitung dengan persentase jumlah responden yang menganggap bunga bank sama dengan riba yang sekaligus tidak melakukan pinjaman dengan tambahan bunga, terhadap total responden. Hasil penelitian menunjukkan bahwa seluruh pedagang muslim di Pasar Basah Mandonga Kota Kendari telah memahami bahwa bunga pinjaman uang sama dengan riba. Meskipun demikian terdapat 16,67 persen responden yang permodalannya bersifat ribawi yang 6,67 persen diantaranya bersumber dari rentenir. Adapun konsistensi persepsi dan aplikasi dari pemahaman akan bunga uang pada pedagang muslim mencapai 83,33 persen.
\end{abstract}

Kata Kunci: persepsi; bunga bank; riba; modal usaha 


\section{PENDAHULUAN}

Bisnis tidak hanya membutuhkan keahlian, namun juga membutuhkan modal. Sehingga fungsi produksi umumya didefinisikan sebagai hubungan antara input (tenaga kerja, modal dan input lainnya) terhadap output. Jumlah modal yang dibutuhkan pada awal mendirikan usaha sangat tergantung pada jenis usaha dan skala usaha yang dilakukan. Usaha atau industri yang membutuhkan lebih banyak modal dibanding tenaga kerja di kenal dengan industri padat modal, sementara jika pengembangan usaha lebih menggunakan tenaga kerja dikenal dengan istilah padat tenaga kerja. Usaha berciri padat modal merupakan usaha dengan skala yang besar. Adapun usaha yang berkembang dengan padat tenaga kerja umumnya merupakan usaha rakyat.

Ciri tersebut tidaklah serta merta menunjukkan bahwa usaha rakyat tak membutuhkan modal. Apapun usaha tersebut, tetap memerlukan input modal, baik sedikit maupun banyak. Dengan demikian, pelaku usaha perlu memiliki kreatifitas dalam pencarian sumber modal bagi usahanya agar tidak membebani bisnis yang dijalankan. Bagi usaha skala kecil, modal dapat saja tertutupi melalui modal milik sendiri. Meskipun demikian tidak sedikit pula pedagang kecil memerlukan tambahan modal untuk ekspansi usaha.

Alternatif sumber modal yang dapat digunakan oleh pelaku usaha yaitu bersumber dari lembaga keuangan, baik formal maupun informal. Lembaga keuangan formal dapat melalui lembaga perbankan. Namun terkadang usaha rakyat masih sulit menjangkau pembiayaan perbankan karena beberapa hal, yaitu: syarat agunan belum mampu dipenuhi, bunga pinjaman terlalu tinggi, pelaku usaha kecil menengah (UKM) enggan berurusan dengan perbankan, karena prosedur pengajuan kredit yang rumit, kurangnya sosialisasi dan informasi mengenai pinjaman lunak yang tersedia untuk mereka, dan sistem pembanyaran kembali kredit yang rutin menjadi beban bagi pengusaha yang penjualan produknya berfluktuasi (Mughni, 2015). Rambo (2013) mengamati bahwa kebanyakan usaha kecil dan menengah tidak mengetahui program pendanaan dan kesulitan dalam mengakses dana untuk berinvestasi dalam proyek-proyek usaha mereka. Sementara temuan penelitian Osano dan Languitone (2016) menunjukkan bahwa rendahnya akses pendanaan perbankan pada usaha kecil menengah disebabkon oleh persoalan jaminan, kesadaran akan peluang pendanaan, infrastruktur pendukung usaha, dan struktur lembaga keuangan.

Pada sisi lain, lembaga keuangan informal sebagai alternatif pelaku usaha dalam meminjam uang, dapat dikelola secara melembaga maupun individu. Salah satu lembaga informal yaitu tengkulak atau rentenir. Kemudahan akses pada lembaga keuangan informal ini dapat memperlambat keuangan inklusif perbankan. Umumnya nasabah rentenir adalah pedagang kecil (Hamka \& Danarti, 2010; Siboro, 2015). Model kerja rentenir ini sangat praktis, tanpa jaminan, dan proses cepat. Hasil penelitian Hamka dan Danarti (2010) menunjukkan bahwa lembaga keuangan informal (bank thithil), memiliki fleksibilitas tinggi dan lebih dapat menjangkau pedagang tradisional. Salah satu fleksibilitas tersebut adalah tercermin dari pada jam berapa mereka beraktivitas dan memiliki kesesuaian waktu dengan pedagang tradisional. Selain itu, terdapat jejaring yang telah terbangun antar pedagang.

Pada sisi lain, jika pelaku usaha ingin melakukan pinjaman pada lembaga keuangan formal seperti perbankan, maka terdapat dua varian bank yang beroperasi di 
Indonesia yaitu bank konvensional dan bank syariah. Bank syariah merupakan bank yang operasionalisasi kegiatannya berdasarkan prinsip syariah (Islam). Prinsip syariah Islam salah satunya yang dimaksud yaitu prinsip bagi hasil yang menggantikan prinsip bunga pada bank konvensional. Pada dasarnya bank syariah telah mendapat dukungan dari Fatwa MUI No 1 Tahun 2004 tentang bunga, yang membawa pesan bahwa bunga bank sama dengan riba. Meskipun Fatwa MUI bukanlah sumber hukum, namun dalam tataran ketatanegaraan fatwa MUI diadaptasi untuk mengakomodir nilai-nilai Islam di Indonesia. Sampai kini, fatwa MUI tersebut masih menjadi perdebatan di kalangan umat Islam. Hal ini diindikasikan dengan masih rendahnya pangsa perbankan syariah. Jumlah aset bank umum syariah dan unit usaha syariah periode Desember 2017 sebesar 424.181 milyar rupiah (OJK, 2018a), sementara aset keseluruhan bank umum di Indonesia pada periode yang sama sebesar 7.387.144 milyar rupiah (OJK, 2018b). Sehingga pangsa bank syariah terhadap total bank di Indonesia sekitar 5,74 persen.

Pada Fatwa MUI No 1 Tahun 2004 Bagian B disebutkan bahwa praktek penggunaan bunga hukumnya adalah haram, baik di lakukan oleh bank, asuransi, pasar modal, pegadaian, koperasi, dan lembaga keuangan lainnya maupun dilakukan oleh individu. Selanjutnya keputusan ketiga terkait dengan bermuamalah dengan lembaga keuangan konvensional pada Bagian A dinyatakan bahwa: (1) untuk wilayah yang sudah ada kantor/jaringan lembaga keuangan syariah dan mudah di jangkau, tidak di bolehkan melakukan transaksi yang di dasarkan kepada perhitungan bunga; namun (2) untuk wilayah yang belum ada kantor/jaringan lembaga keuangan syariah, diperbolehkan melakukan kegiatan transaksi di lembaga keuangan konvensional berdasarkan prinsip dharurat/hajat.

Pada akhirnya, pilihan pelaku usaha untuk pengajuan pinjaman pada lembaga yang dituju tergantung dari aspek suku bunga dan agunan (Nababan \& Hamoraon, 2013), serta pelayanan atau sistem administrasi (Maski, 2010; Nababan \& Hamoraon, 2013). Selanjutnya pilihan juga dapat tergantung pada pemahaman dan/atau persepsi nilai-nilai agama (Rahmawaty, 2014). Beberapa studi telah menunjukkan pengaruh signifikan persepsi terhadap keputusan (Mawey, 2013; Rahmawaty, 2014; Cahyani, Saryadi \& Nurseto, 2013). Namun hasilnya berbeda dengan penelitian Fauzan (2013) menunjukkan bahwa pemahaman nilai agama tidak berpengaruh terhadap penerapan etika bisnis. Hal ini mengindikasikan bahwa meskipun seseorang telah memahami ajaran agama, namun belum tentu menerapkan ajaran tersebut.

Berdasarkan studi tersebut, maka penelitian ini diarahkan pada konsistensi pemahaman agama (dalam hal ini persepsi pedagang atas kesamaan bunga dengan riba) terhadap perilaku bisnis (pemenuhan sumber modal usaha) pedagang muslim. Dengan demikian kebaruan dari tulisan ini yaitu konsistensi antara persepsi tentang bunga bank dan aplikasi pada pemenuhan kebutuhan modal usaha. Dengan kata lain, tulisan ini akan mengungkap apakah seseorang yang memiliki pemahaman bahwa bunga bank sama dengan riba, tidak melakukan pinjaman berbasis bunga. Studi ini dilakukan di Kota Kendari dengan ruang lingkup khusus pedagang tradisional, yang memiliki skala usaha kecil, membutuhkan modal usaha yang kecil namun terbatas dalam mengakses pinjaman. 


\section{METODE PENELITIAN}

Penelitian ini menggunakan data primer yang dikumpulkan secara langsung dari pedagang muslim di Pasar Basah Mandonga Kota Kendari. Populasi penelitian yaitu seluruh pedagang muslim yang menjual barang campuran dan memiliki lokasi/los permanen yang berjumlah 30 orang. Sampel penelitian menggunakan metode sensus, atau dengan kata lain seluruh populasi dijadikan sampel penelitian. Teknik pengumpulan data menggunakan kuisioner. Persepsi responden akan bunga bank sama dengan riba diukur dengan pilihan jawaban setuju dan tidak setuju (bunga bank sama dengan riba). Indikator responden termasuk dalam kelompok yang memiliki sumber dana ribawi yaitu responden yang menggunakan modal dari lembaga keuangan konvensional dan atau rentenir; sementara responden yang berada pada kategori pendanaan non ribawi yaitu responden yang tidak menggunakan kedua sumber dana ribawi tersebut. Metode analisis yang digunakan untuk mengetahui konsistensi responden atas persepsi tentang bunga bank dan perilaku peminjaman dana usaha, maka digunakan matriks 4 kuadran. Matriks 4 kuadran merupakan matriks yang mengelompokkan responden ke dalam 4 kategori, sebagaimana Bagan 1. Responden yang berada pada Kuadran I merupakan responden yang memiliki indikator konsisten, yaitu mempersepsikan bunga bank sama dengan riba, sehingga menggunakan sumber dana yang tidak berasal dari lembaga keuangan ribawi. Untuk menghitung tingkat konsistensi responden, maka digunakan rumus persentase, yaitu:

$$
\mathrm{k}=\mathrm{K} \_1 / \mathrm{n} \times 100 \text {. }
$$

Sumber: modifikasi peneliti

keterangan:

$\mathrm{k}=$ tingkat konsistensi

$\mathrm{K}_{1}=$ jumlah responden pada Kuadran I

$\mathrm{n} \quad=$ jumlah sampel

\begin{tabular}{|c|c|c|c|}
\hline \multirow{2}{*}{\multicolumn{2}{|c|}{ Ribawi }} & \multicolumn{2}{|c|}{ Sumber Modal } \\
\hline & & Non Ribawi & \\
\hline \multirow[b]{2}{*}{$\begin{array}{c}\text { Persepsi } \\
\text { Tentang } \\
\text { Bunga }\end{array}$} & Riba & $\begin{array}{c}\text { Kuadran II } \\
\text { responden dengan persepsi } \\
\text { bunga= riba; dan namun } \\
\text { sumber dana berasal dari } \\
\text { ribawi }\end{array}$ & $\begin{array}{c}\text { Kuadran I } \\
\text { responden dengan persepsi bun- } \\
\text { ga= riba dan sumber dana berasal } \\
\text { dari non ribawi }\end{array}$ \\
\hline & $\begin{array}{c}\text { Bukan } \\
\text { Riba }\end{array}$ & $\begin{array}{c}\text { Kuadran IV } \\
\text { responden dengan persep- } \\
\text { si bunga } \neq \text { riba; namun } \\
\text { sumber dana berasal dari } \\
\text { ribawi }\end{array}$ & $\begin{array}{c}\text { Kuadran III } \\
\text { responden dengan persepsi bun- } \\
\text { ga } \neq \text { riba, dan sumber dana berasal } \\
\text { dari non ribawi }\end{array}$ \\
\hline
\end{tabular}

Sumber: Modifikasi Peneliti

Bagan 1. Matrik IV Kuadran Sumber Modal dan Persepsi Tentang Bunga 


\section{HASIL DAN PEMBAHASAN}

\section{Hasil Penelitian}

\section{a. Karakteristik Responden Berdasarkan Tingkat Pendidikan}

Distribusi responden berdasarkan tingkat pendidikan yang diukur dengan jenjang studi ijasah terakhir yang diperoleh disajikan sebagaimana Tabel 1, yang menunjukkan bahwa mayoritas responden atau sekitar 60 persen merupakan lulusan Sekolah Menengah Atas (SMA), dan 13,33 persen diantaranya merupakan lulusan Perguruan Tinggi (PT), dan selebihnya merupakan lulusan Sekolah Menengah Pertama (SMP).

Tabel 1. Distribusi Responden Berdasarkan Tingkat Pendidikan

\begin{tabular}{|c|c|c|c|}
\hline No & Tingkat Pendidikan & Jumlah Responden & Persentase \\
\hline 1 & SMP & 8 & 26,67 \\
\hline 2 & SMU & 18 & 60,00 \\
\hline 3 & PT & 4 & 13,33 \\
\hline
\end{tabular}

Sumber : Hasil Penelitian (2015)

b. Karakteristik Responden Berdasarkan Persepsi Akan Kesamaan Bunga Bank dengan Riba

Berdasarkan hasil penelitian sebagaimana Tabel 2 menunjukkan bahwa seluruh responden, atau 100 persen mempersepsikan bahwa bunga bank sama dengan riba, sehingga tidak ada responden yang tidak setuju akan keharaman bunga bank.

Tabel 2. Distribusi Responden Berdasarkan Pandangan atas Bunga Bank Sama Dengan Riba

\begin{tabular}{clcc}
\hline No. & Keterangan & Jumlah responden & Persentase \\
\hline 1 & Setuju & 30 & 100 \\
2 & Tidak setuju & 0 & 0 \\
\hline & Total & 30 & $100 \%$ \\
\hline
\end{tabular}

Sumber : Hasil Penelitian (2015)

\section{c. Karakteristik Responden Berdasarkan Sumber Modal}

Kebutuhan modal awal responden untuk berdagang di Pasar Basah Kota Kendari bervariasi sebagaimana Tabel 3, namun mayoritas responden atau 43,33 persen memiliki modal awal untuk berdagang antara 6-10 juta rupiah. Bahkan terdapat 4 responden atau 13,34 persen yang memiliki modal awal lebih kecil dari 5 juta rupiah Jika dibandingkan dengan kebutuhan awal usaha, baik untuk sewa tempat dan pembelian barang dagangan maka mengindikasikan bahwa sebagian besar pedagang muslim di pasar basah membutuhkan tambahan modal dari luar. 
Tabel 3. Distribusi Responden Berdasarkan Modal Awal

\begin{tabular}{cccc}
\hline No & Modal Awal (Rp) & Jumlah Reponden & Persentase (\%) \\
\hline 1 & $\leq 5.000 .000$ & 4 & 13,34 \\
2 & $6.000 .000-10.000 .000$ & 13 & 43,33 \\
3 & $11.000 .000-15.000 .000$ & 7 & 23,33 \\
4 & $>15.000 .000$ & 6 & 20,00 \\
\hline & Total & 30 & 100,00 \\
\hline
\end{tabular}

Sumber : Hasil Penelitian (2015)

Adapun distribusi responden berdasarkan modal usaha disajikan sebagaimana Tabel 4. Tabel 4 menyajikan bahwa sebanyak 83,33 persen memiliki sumber modal dari milik sendiri, dan sebanyak 16,63 persen menggunakan sumber modal dari luar, baik dari bank konvensional (sebanyak 10 persen responden), maupun bersumber dari rentenir (sebanyak 6,63 persen). Pilihan atas sumber permodalan ini dapat dipengaruhi oleh pandangannya atas bunga bank.

Hasil penelitian juga menunjukkan bahwa terdapat beberapa alasan responden untuk tidak menggunakan jasa lembaga keuangan. Alasan tersebut diantaranya yakni: (1) memiliki ketercukupan modal usaha; (2) modal diperoleh dari usaha sendiri; (3) menghindari resiko pinjaman; (4) prinsip dari pedagang yang tidak mau meminjam; (5) keuntungan usaha dagang yang dapat digunakan sebagai modal; dan (6) pemasok memberikan kemudahan pedagang dalam pembayaran barang dagangan.

Tabel 4. Distribusi Responden Berdasarkan Sumber Modal

\begin{tabular}{clcc}
\hline No & Sumber modal & Jumlah Responden & Persentase \\
\hline 1 & Modal sendiri/pribadi & 25 & 83,33 \\
2 & Rentenir & 2 & 6,63 \\
3 & Bank Konvensional & 3 & 10,00 \\
\hline & Jumlah & 30 & 100,00 \\
\hline
\end{tabular}

Sumber : Hasil Penelitian (2015)

Responden penelitian dalam melaksanakan kegiatan perdagangannya menggunakan modal pribadi bersumber dari simpanan/tabungan, usaha lain yang dilakukan oleh pedagang, dan sebagainya. Responden yang menggunakan modal sendiri tersebut memiliki alasan menggunakan modal usaha sendiri dari pada harus meminjam kepada lembaga keuangan. Salah satu alasan tersebut yaitu modal yang dibutuhkan dalam berdagang masih dapat tercukupi dari modal yang dimiliki sendiri. Responden yang menggunakan modalnya sendiri ini berusaha sendiri agar usahanya bisa tetap berjalan tanpa bergantung dari orang lain sehingga setiap keuntungan yang diperoleh juga akan diterima untuk mereka sendiri. Ketercukupan modal yang dimiliki oleh responden tersebut kemudian dikelola untuk membeli barang-barang dagangan dan biaya-biaya lain yang harus dikeluarkan setiap harinya.

Selain modal yang masih mencukupi yang dimiliki, responden juga tidak meminjam karena tidak memerlukan modal yang besar dan masih bisa dipenuhi dari kemampuan modalnya sendiri. Responden muslim yang berdagang di Pasar Basah Mandonga yang memiliki usaha dagang dengan skala kecil tidak akan meminjam 
kepada lembaga keuangan. Skala usaha yang kecil membuat modal yang diperlukan pun juga kecil dan masih bisa dipenuhi dengan modal sendiri. Pada sisi lain, responden lebih memilih menggunakan modal sendiri juga karena alasan rasa takut untuk meminjam kepada lembaga keuangan agar terhindar dari risiko pembayaran. Meskipun lembaga keuangan formal maupun informal merupakan lembaga untuk memperoleh sumber permodalan, namun dengan berbagai risiko yang bisa muncul terkait pembayaran di lembaga keuangan, membuat responden enggan untuk mengajukan pinjaman. Responden yang memiliki modal sendiri akan bertumpu pada sumber dana pribadi dan tidak menggunakan jasa lembaga keuangan, karena takut tidak sanggup membayar sehingga memberatkan usaha dagangnya.

Pada sisi lain, tidak semua responden berminat untuk menggunakan jasa layanan lembaga keuangan. Hal tersebut dikarenakan pedagang memiliki alasan yakni telah berprinsip untuk tidak meminjam dan memilih untuk bekerja keras. Responden berprinsip untuk tidak meminjam tersebut dari awal berdagang memang tidak memiliki niat untuk meminjam. Responden telah terbiasa untuk berusaha atau berkerja keras guna memenuhi kebutuhan sehari-hari dan untuk usaha dagangnya. Manfaat bagi responden membuatnya tidak bergantung kepada pihak lain, dan dari segi penghasilan tentunya responden akan menikmatinya sendiri. Responden juga telah merasakan manfaatnya yaitu sudah tidak harus bekerja keras lagi dalam usaha dagang dan tidak ada kesulitan yang dihadapi terkait pendanaan. Alasan lain yang menyebabkan keengganan responden untuk meminjam yaitu karena mereka mampu menyisihkan sebagian keuntungannya untuk menambah modal. Keuntungan yang diperoleh bukan hanya digunakan untuk pemenuhan kebutuhan sehari-hari, namun juga digunakan sebagai modal berdagang. Oleh karena itu, dengan keuntungan yang didapatkan akan dapat menjaga kecukupan modal.

Selanjutnya bahwa tidak digunakannya sumber keuangan dari lembaga keuangan dalam memenuhi kebutuhan modal pada responden juga disebabkan oleh fleksibilitas sistem pembayaran dari pemasok barang. Pedagang pasar tradisional dalam menjalankan usaha dagang memerlukan pasokan barang dagang dari pemasok. Pedagang setiap hari harus melakukan transaksi pembelian barang dari pemasok untuk kemudian dijual kembali di pasar. Namun kendalanya bahwa pedagang tidak selalu setiap hari dapat memperoleh penghasilan yang maksimal. Pada saat tertentu, pedagang dapat memperoleh penghasilan yang maksimal namun pada saat lain tidak. Kendala tersebut tentunya membuat pedagang kesulitan untuk membeli barang dagangan dari pemasok karena penghasilan yang tidak mencukupi.

Namun hal tersebut dapat teratasi apabila pemasok tidak memberatkan pedagang dalam hal pembayaran. Hal tersebut juga menjadi alasan responden untuk tidak perlu meminjam kepada lembaga keuangan dan tetap bisa menjalankan usaha dagangnya dengan modal yang dimiliki. Pada saat pedagang tidak mempunyai modal untuk persediaan barang dagangan yang akan dijual di hari berikutnya, responden akan mengambil barang dagangan terlebih dahulu dari pemasok kemudian di jual, sementara pembayaran ke pemasok akan dilakukan saat barang dagangan telah terjual.

Meskipun secara umum responden memperoleh manfaat dengan sistem ini dan tidak memiliki pinjaman dari sumber lain, namun terdapat 2 orang responden yang tetap meminjam pada rentenir. Berdasarkan hasil penelitian, alasan responden memiliki sumber 
permodalan dari rentenir yaitu: (1) proses yang tidak rumit; (2) prosedur pembayaran yang tidak memberatkan; dan (3) kebutuhan modal yang mendesak.

Pedagang juga akan memperoleh kemudahan dari sisi administrasi apabila meminjam modal pada rentenir dibanding lembaga keuangan. Kemudahan tersebut tidak akan diperoleh pedagang jika meminjam di lembaga keuangan formal seperti bank. Rentenir tidak akan memberatkan dalam hal jaminan dan persyaratan-persyaratan yang rumit. Namun, bunga yang tinggi menjadi satu-satunya hal yang memberatkan pedagang apabila meminjam di rentenir. Menurut penjelasan responden, proses meminjam di rentenir sangat mudah dan cepat. Hanya dalam jangka waktu tiga hari responden sudah mendapatkan pinjaman yang dibutuhkan. Selain itu, responden pun juga untuk meminjam tidak perlu menyerahkan jaminan yang tentu saja hal tersebut sangat memudahkan.

Responden yang menggunakan jasa rentenir juga memperoleh kemudahan dalam hal pembayaran. Responden dapat membayar cicilan pembayaran sesuai dengan kemampuan. Hal tersebut juga disebabkan karena peminjam dapat memilih sendiri tingkat bunga yang bersedia dibayar kepada rentenir. Jika bunga yang dipilih lebih tinggi, maka cicilan per harinya akan rendah namun jangka waktu pelunasannya semakin lama. Sebaliknya, jika bunga yang dipilih rendah, maka cicilan per harinya tinggi atau jangka waktu pelunasannya semakin cepat. Besarnya bungapun terbilang relatif tinggi berkisar 20 persen. Meskipun bunganya tinggi, tampaknya responden tidak merasa terbebani karena cicilan per harinya disesuaikan dengan kemampuannya dan telah dapat dipenuhi.

Alasan keterpaksaan juga menjadi salah satu penyebab responden meminjam uang pada rentenir. Beberapa pedagang kecil yang memerlukan kebutuhan modal yang mendesak dapat menggunakan jasa rentenir untuk memenuhi kebutuhan modalnya. Rentenir sebagai lembaga keuangan informal mampu menyediakan modal dengan proses yang cepat. Sehingga pedagang yang memerlukan kebutuhan modal yang mendesak pun dapat memanfaatkan jasa rentenir tersebut agar ketercukupan modalnya dapat terjaga. Apabila responden yang membutuhkan modal yang mendesak harus meminjam ke lembaga keuangan formal, tentunya akan mengalami kesulitan terutama untuk memenuhi persyaratan yang ditetapkan dan proses yang relatif panjang. Responden pun beralih meminjam kepada rentenir agar kebutuhan modalnya yang mendesak dapat segera terpenuhi.

Namun bagi responden yang memperoleh pinjaman dari kembaga formal dalam hal ini perbankan konvensional memiliki pandangan yang berbeda dengan responden yang meminjam pada rentenir. Responden yang melakukan pinjaman pada bank lembaga keuangan formal tetap menganggap bahwa prosedur perbankan relatif mudah. Bank memberikan kelebihan dan kemudahan bagi pedagang yang membutuhkan modal usaha. Selain terjamin dari sisi hukumnya bank juga dapat menyalurkan pinjaman dalam jumlah besar, prosedur yang relatif mudah dan proses pencairannya juga dapat dikatakan tidak lama. Berdasarkan informasi yang diungkapkan oleh Bapak Bakri dan Ibu Wama yang juga merupakan pedagang di Pasar Basah Mandonga, bahwa salah satu alasan pedagang Pasar Basah Mandonga lebih memilih jasa lembaga perbankan dari pada lembaga keuangan lain yakni proses pencairan modal pinjaman yang cepat. Responden dapat mencairkan pinjamannya hanya dalam jangka waktu 3 hari - 1 minggu Selain itu, responden juga memiliki alasan tersendiri menggunakan fasilitas pinjaman dari perbankan. Salah satu alasan tersebut yaitu responden memiliki relasi yang dikenal 
yang berada di dunia perbankan. Relasi tersebut yang membantu pedagang dalam memperoleh pinjaman. Reseponden pun juga lebih banyak memperoleh informasi dan terbantu dengan adanya relasi di bidang perbankan tersebut.

Responden yang memilih untuk memanfaatkan fasilitas pinjaman di bank karena lebih terpercaya serta menerapkan sistem bunga yang rendah sehingga tidak memberatkan pedagang. Rentenir sebagai lembaga keuangan informal dianggap memberatkan pedagang di Pasar Basah Kota Kendari karena menerapkan tingkat bunga 20 persen, lebih tinggi dibanding bank. Tingginya suku bunga membuat pedagang justru kurang dapat memanfaatkan pinjamannya tersebut karena harus membayar pinjaman yang jauh lebih tinggi.

\section{d. Konsistensi Persepsi Responden Tentang Bunga Bank dan Perilaku Peminjaman Modal}

Tabel 2 menunjukkan bahwa seluruh responden mempersepsikan bunga bank sama dengan riba. Namun Tabel 4 menunjukkan bahwa masih terdapat 5 orang responden yang menggunakan sumber permodalan yang mengandung unsur bunga, baik bunga bank maupun bunga rentenir. Jika Tabel 2 dan 4 disajikan dalam bentuk matriks, maka dapat dihasilkan distribusi responden sebagaimana Tabel 5. Tabel 5 menyajikan bahwa sebanyak 5 responden responden di Pasar Basah Mandonga Kota Kendari memiliki sumber permodalan dari ribawi meskipun beranggapan bahwa bunga itu sama dengan riba. Selanjutnya terdapat 25 responden responden yang memiliki sumber permodalan dari non ribawi. Hal ini menunjukkan bahwa tingkat konsistensi responden atas apa yang dipersepsikan dan aplikasinya sebesar $=(25 / 30) \times 100$, atau 83,33 persen; dan selebihnya 16,67 persen berada pada kriteria tidak konsisten.

Tabel 5. Konsistensi Perilaku dan Persepsi Responden Tentang Bunga Bank

\begin{tabular}{cccc}
\hline \multirow{2}{*}{ Ribawi } & & \multicolumn{2}{c}{ Sumber Dana } \\
\cline { 2 - 4 } & Riba & 5 & Bukan Ribawi \\
\hline Pandangan & Bukan Riba & 0 & 0 \\
Tentang Bunga Bank & &
\end{tabular}

Sumber : Hasil Penelitian (2015)

\section{Pembahasan}

Hasil penelitian menunjukkan bahwa sumber permodalan pedagang muslim di Pasar Basah Mandonga Kota Kendari bersumber dari modal sendiri dan pinjaman. Sumber pinjaman pedagang berasal dari lembaga keuangan formal yang dalam hal ini adalah bank konvensional maupun lembaga keuangan non formal. Hasil penelitian sejalan dengan penelitian Oktavianingtyas (2015) untuk kasus pedagang tradisional Dinoyo Kota Malang. Selanjutnya temuan penelitian menunjukkan bahwa pedagang muslim di Pasar Basah Mandonga Kota Kendari telah memahami bahwa bunga pinjaman sama dengan riba sebagaimana Fatwa MUI No. 1 Tahun 2004. Pada sisi lain, hasil penelitian juga menunjukkan bahwa terdapat 16,67 responden yang melakukan pinjaman dengan bunga, dan 6,67 persen diantaranya melalui rentenir.

Responden tidak memiliki hutang pada awal usaha karena beberapa alasan: (1) memiliki ketercukupan modal usaha; (2) modal diperoleh dari usaha sendiri; (3) menghindari resiko pinjaman; (4) prinsip dari pedagang yang tidak mau meminjam; 
(5) keuntungan usaha dagang yang dapat digunakan sebagai modal; dan (6) pemasok memberikan kemudahan pedagang dalam pembayaran barang dagangan. Adapun alasan pedagang yang melakukan pinjaman ke rentenir, yaitu: (1) proses yang tidak rumit; (2) prosedur pembayaran yang tidak memberatkan; dan (3) kebutuhan modal yang mendesak. Meskipun demikian, hasil penelitian menunjukkan bahwa bunga yang diberikan oleh rentenir terbilang tinggi berkisar 20 persen. Padahal tingkat bunga ini memiliki pengaruh negatif terhadap kemampuan pengembalian dana (Priyadi, 2014) .

Proses pinjaman rentenir yang tidak berbelit merupakan salah satu daya tarik pedagang kecil meminjam uang kepada rentenir, temuan ini sejalan dengan penelitian Siboro (2015) yang menunjukkan bahwa selain syarat pinjaman rentenir yang mudah dan efisien dibandingkan dengan lembaga peminjaman lainnya seperti bank, peminjaman juga tidak memerlukan jaminan serta persyaratan yang sulit lainnya. Studi Hamka dan Danarti (2010) menunjukkan bahwa rentenir sangat mudah menjangkau pedagang karena memiliki jaringan. Pelaku rentenir (bank thithil) berasal dari jaringan internal maupun eksternal. Rentenir yang berasal dari internal merupakan rentenir yang pekerjaan utamanya adalah berdagang sedangkan praktik 'bank thithil' yang dilakukan hanya sebagai kegiatan off-trading. Sedangkan bank thithil yang pelakunya berasal dari eksternal pasar, memposisikan kegiatan 'bank thithil' sebagai usaha utama (core bussines). Lebih jauh lagi, bank thithil seperti layaknya 'badan usaha' yang mapan juga mempunyai 'pegawai' untuk melakukan operasional usahanya.

Selanjutnya masalah kedaruratan atau keterpaksaan memang masih menjadi alasan masyarakat yang telah memahami hukum Islam namun tetap melakukan apa yang dilarang, mereka merujuk pada Al Quran QS. Al Baqarah ayat 173 dan QS. Al An'am ayat 119 yang artinya:

'Tetapi barangsiapa dalam keadaan terpaksa (memakannya) sedang dia tidak menginginkannya dan tidak (pula) melampaui batas, maka tidak ada dosa baginya." (QS. Al Baqarah: 173).

"Padahal sesungguhnya Allah telah menjelaskan kepada kamu apa yang diharamkanNya atasmu, kecuali apa yang terpaksa kamu memakannya." (QS. Al An'am: 119).

Namun sebenarnya yang perlu dikaji lebih lanjut yaitu bagaimana konteks kedaruratan atau keterpaksaan tersebut, apakah tidak ada alternatif atau upaya lainnya hingga harus meminjam pada individu atau lembaga yang menerapkan aturan bunga. Sebagaimana Fatwa MUI No. 1 Tahun 2004 dinyatakan pada Bagian A No. 2, bahwa dalam hal peminjaman/pemanfaatan uang dengan bunga adalah darurat jika belum ada kantor/jaringan lembaga keuangan syariah.

Hasil penelitian juga menunjukkan bahwa pedagang muslim telah menunjukkan konsistensinya atas persepsi dan aplikasi persepsi sebesar 83,33 persen. Temuan ini sesuai dengan penelitian Kurniati (2012), Rahmawaty (2014), Mohammad dan Mustofa (2014), serta Cahyani, Saryadi, dan Nurseto (2013), bahwa pemahaman akan nilai-nilai agama akan mempengaruhi perilaku dan atau keputusan bisnis seseorang. 


\section{KESIMPULAN}

Pedagang muslim yang ada di Pasar Basah Mandonga di Kota Kendari memiliki sumber permodalan dari modal sendiri, modal dari rentenir dan berasal dari bank konvensional. Terdapat 16,67 persen responden yang permodalannya bersifat ribawi yang 6,67 persen diantaranya bersumber dari rentenir, sisanya 10 persen bersumber dari bank konvensional. Pada sisi lain, pedagang muslim di Pasar Basah Mandonga Kota Kendari telah memahami bahwa bunga pinjaman uang sama dengan riba dalam pandangan Islam sebagaimana Fatwa MUI No.1 tahun 2004. Konsistensi persepsi dan aplikasi dari pemahaman akan bunga uang pada pedagang muslim mencapai 83,33 persen. Beberapa alasan yang mendukung konsistensi tersebut, yaitu: (1) memiliki ketercukupan modal usaha; (2) modal diperoleh dari usaha sendiri; (3) menghindari resiko pinjaman; (4) prinsip dari pedagang yang tidak mau meminjam; (5) keuntungan usaha dagang yang dapat digunakan sebagai modal; dan (6) pemasok memberikan kemudahan pedagang dalam pembayaran barang dagangan.

\section{SARAN DAN REKOMENDASI}

Saran yang diajukan terkait penelitian ini diantaranya: (a) bank syariah perlu melakukan sosialisasi maupun edukasi mengenai produk dan syarat-syarat peminjaman dana disertai dengan kemudahan memperoleh dana tersebut, (b) hendaknya Otoritas Jasa Keuangan memberikan edukasi keuangan bagi masyarakat mengenai sumber pendanaan usaha alternatif non ribawi selain lembaga perbankan, dan (c) bagi peneliti lain, diharapkan dapat mengkaji faktor yang mempengaruhi konsistensi perilaku tersebut melalui metodologi inferensial.

\section{DAFTAR PUSTAKA}

Cahyani, A. F., Saryadi., \& Nurseto, S. (2013). Pengaruh Persepsi Bunga Bank dan Kualitas Pelayanan Terhadap Minat Menabung pada Bank BNI Syariah di Kota Semarang. Diponegoro Journal of Social and Politic, 2(3), 1-8. Diakses dari http://ejournals1.undip. ac.id/index.php/

Fauzan. (2013). Pengaruh Religiusitas Terhadap Etika Berbisnis (Studi Pada Rumah Makan. Padang di Kota Malang). Jurnal Manajemen dan Kewirausahaan, 15(1), 53-64. doi: 10.9744/jmk.15.1.53-64

Hamka, A. A., \& Danarti, T. (2010). Eksistensi Bank Thithil Dalam Kegiatan Pasar Tradisional (Studi Kasus di Pasar Kota Batu). Journal of Indonesian Applied Economics, 4(1), 58-70. Diakses dari http://jiae.ub.ac.id/index.php/jiae/article/view/119/94

Kurniati. (2012). Analisis Persepsi dan Preferensi Nasabah Muslim dan Nasabah Non Muslim Terhadap Keputusan Memilih Perbankan Syariah di Provinsi DIY (Studi Kasus di Bank Syariah Mandiri Cabang Yogyakarta dan Bank Pembangunan Daerah DIY Syariah). Jurnal Ekonomi Syariah Indonesia, 2(2), 251-276. Diakses dari http://ejournal.almaata. ac.id/index.php/JESI/article/view/357

Maski, G. (2010). Analisis Keputusan Nasabah Menabung: Pendekatan Komponen dan Model Logistik Studi pada Bank Syariah di Malang. Journal of Indonesian Applied Economics, 4(1), 43-57. Diakses dari http://jiae.ub.ac.id/index.php/jiae/article/view /120/147

Mawey, H. E. (2013). Motivasi, Persepsi, dan Sikap Konsumen Pengaruhnya Terhadap Keputusan Pembelian Produk PT. Rajawali Nusindo Cabang Manado. Jurnal EMBA 1 (4), 791-801. Diakses dari https://ejournal. unsrat.ac.id/index. php/emba/ article/ view/2807 
Mohammad, R., \& Mustofa (2014). Pengaruh Tingkat Pemahaman Agama Terhadap Perilaku Bisnis Pedagang Pasar Minggu Telaga Kabupaten Gorontalo. Jurnal Al-Mizan, 10(1), 1-16. Diakses dari http://download.portalgaruda.org

Mughni, A. (2015). Keuangan Islam Untuk Wong Cilik (Miskin). Jurnal Muqtasid, 6(1), 125-139. Diakses dari http://muqtasid.iainsalatiga.ac.id/index.php/muqtasid/article/view/ 1025/699

MUI. (2004). Fatwa MUI No. 1 Tentang Bunga (Interest/Fa'idah). Diakses dari http://muijatim. org/wp-content/uploads/2016/09/Bunga-InterestFaidah_2004.pdf

Nababan, D. I., \& Hamoraon, H. D. (2013). Analisis Faktor-Faktor yang Mempengaruhi Keputusan Masyarakat Kecamatan Medan Helvetia Dalam Memilih Lembaga Keuangan Sebagai Sumber Pendanaan. Jurnal Ekonomi dan Keuangan, 1 (6), 17-24. Diakses dari https://jurnal.usu.ac.id/index.php/edk/article/view/9224

OJK. (2018a). Statistik Perbankan Syariah-Desember 2017. Diakses dari: www.ojk.go.id OJK. (2018b). Statistik Perbankan Indonesia-Desember 2017. Diakses dari: www.ojk.go.id

Oktavianingtyas, K. W. (2015). Preferensi Pedagang Tradisional Terhadap Sumber Pembiayaan Usaha (Studi di Pasar Tradisional Kota Malang). Jurnal Ilmiah Mahasiswa FEB UB, 3 (1), 1-18. Diakses dari http://download.portalgaruda.org

Osano, H. M., \& Languitone, H. (2016). Factors Influencing Access to Finance by SMEs in Mozambique: Case of SMEs in Maputo Central Business District. Journal of Innovation and Entrepreneurship, 5(13), 1-16. doi:10.1186/s13731-016-0041-0

Priyadi, U. (2014). Analisis Faktor-Faktor yang Mempengaruhi Pengembalian Pinjaman BMT di Kecamatan Ngaglik tahun 2012. Jurnal Aplikasi Bisnis, 15(9), 1761-1776. doi: 10.20885/ jabis.vol15.iss9.art1

Rahmawaty, A. (2014). Pengaruh Persepsi Tentang Bank Syari'ah Terhadap Minat Menggunakan Produk di BNI Syari'ah Semarang, 8(1), 1-28. Diakses dari https://media.neliti.com/ media/publications/53231-ID-none.pdf

Rambo, C. M. (2013). Time Required to Break-Even for Small and Medium Enterprises: The Evidence from Kenya. The International Journal of Marketing Research and Management, 6(1), 81-94. Diakses dari https://ssrn.com/abstract=2262538

Siboro, I.K. (2015). Rentenir, Analisis Terhadap Fungsi Pinjaman Berbunga Dalam Masyarakat Rokan Hilir Kecamatan Bagan Sinembah Desa Bagan Batu. JOM Fisip, 2 (2), 1-15. Diakses dari https://jom.unri.ac.id/index.php/JOMFSIP/article/view/5287 